\title{
E-Government Approach in Building Information Systems for Public Services
}

\author{
Ni Luh Yulyana Dewi*, A.A. Istri A. Maheswari, Ni Luh Yuni Lestari, Ni Putu \\ Bayu Widhi Antari, I Nyoman Subanda
}

Pendidikan Nasional University

Corresponding Email: yulyanadewi@undiknas.ac.id

\begin{abstract}
Developing e-government is one of the efforts to improve the quality of public services effectively and efficiently. In other words, through the e-government approach, management systems and work processes are structured within the government by optimizing information and communication technology (ICT) used. Put, e-government, also known as digital government, is an activity in which the government uses information technologies to provide services. This paper is written utilizing an observation approach, interviews, and literature studies that discussed the fundamentals of egovernment. E-government uses information technologies to strengthen the relationship between the government and other stakeholders to create a partnership for the betterment of people, according to the research findings of the egovernment strategy in developing information networks for public services.
\end{abstract}

Keywords: E-government, Information Systems, Public Services

\section{INTRODUCTION}

It was understanding public service information systems that discuss advances in information. In essence, E-Government uses information technology to improve relations between the government and other parties (Coursey \& Norris, 2008). Enables the achievement of elements of the governance management agenda (Al-Sobhi \& kamal, 2010).

The development of science and technology, which is marked by advances in the field of communication and information technology, has now become so fast that it puts a nation in a position to which the government has advanced based on how far the country has mastered the two fields mentioned above (Arduini \& Zanfei,2010). The Indonesian government is one of the nations that live in a global environment, so inevitably, it must also be involved in the progress and retreat of the mastery of science and technology, especially for the nation's benefit. To achieve this goal, the government puts it in one form of the goals and directions of National Development, namely the Science and Technology Sector (Zouridis,2003).

Along with developing information and communication technology, human life activities in various sectors are changing (Moon, 2005). Likewise, in the government's public service sector, the development of information and communication technology has given birth to a model of shared services carried out through e-Government. Government services that are bureaucratic and seem rigid are eliminated through e-Government to become more flexible and more oriented towards user satisfaction (Rose \& Irani, 2015). E-Government offers public services that can be accessed 24 hours, anytime, and from wherever the user is. E-Government also allows public services not to be done face-to-face so that services become more efficient. Realizing the great benefits of e-Government, the Indonesian government, since 2020, has issued a policy on the application of eGovernment in the form of Presidential Instruction Number 3 of 2003 (Apostolou, 2011).

Realizing the great benefits of information technology, the Sragen Regency Government has the initiative to build Information and Communication Technology (ICT) networks as a solution to overcome the constraints of limited access between regions. The ICT network development initiative began in 2018 (Gajendra \& Wang, 2012). The Electronic Data 
Management Office was given the authority and responsibility to carry out research and development activities and information technology management. As a result, the ICT network's overall development was completed in 2007 so that the online Sragen ICT network could run well.

\section{METHOD}

This research uses a qualitative approach. The technique of determining informants was carried out purposively, in which the selected informants were the ones who were considered to know and understand the most about the problems in this study. It develops using the snowball technique, where the selection of advanced informants to extract data to obtain variety and depth of information is obtained based on references or recommendations from key informants (Hiller, 2001). Analysis techniques used qualitative data analysis techniques following Miles and Huberman. This analysis consists of three lines, namely: (1) data reduction; (2) Presentation of data done using narrative text form; and (3) Concluding (Apriyanti, 2016).

\section{RESULTS AND DISCUSSION}

With the existence of e-government services that were created to improve citizen-centered information and services. The importance of egovernment includes (1) encouraging a government that is responsive to the needs and aspirations of the people; (2) encouraging the utilization side of information disclosure; and (3) encouraging the level of public participation in the government administration system (Irani \& Montazemi, 2007).

The concept of e-government has developed due to three primary triggers, namely: 1.The era of globalization, which is coming faster than expected, has created issues such as democratization. The closeness between the community (as customers) and economic actors (traders, investors, companies and others) has resulted in the formation of a service standard that is getting better over time (Schelin, 2007).

The three aspects above caused pressure from the public, who wanted the government to significantly improve its performance by utilizing existing information and communication technology (Layne \& Lee, 2001). At least four classifications of the relationship between this new form of information and communication technology: 1. Government to Citizens
(G-to-C): G-to-C type is an application. Most commonly, the government builds and implements various information technology portfolios to interact with the public; 2. (G-to-B) (Rahman \& Rohmana, 2018): Type G-to-B is a form of providing information services to businesses; 3. (G-to-G): E-government applications are also needed in interacting between one government and another (government to government) to facilitate cooperation; 4. Government to Employees (G-to-E): This type of G-to-E application is intended internally for staff in government agencies (Mohamed, 2020).

\section{E-Government Implementation Strategy}

So far in Indonesia, there is still a view that egovernment is government-assisted by computers, so simply installing computers and operating them is considered e-government.

To maximize the benefits of e-Government, adequate process control is required in the $\mathrm{e}$ government life cycle to ensure that the system implemented is appropriate for be accounted for, operate well, and support the achievement of regional goals.

This will later be used as a source of information to analyze the e-Government project that will be carried out. Apart from that, the vision of eGovernment must also be determined, the process of assessing the readiness of e-Government implementation, and identifying what to want to achieve (Osei, 2017).

\section{Service Delivery}

The resulting services must be following the objectives of e-Government implementation, namely describing plans locally and regionally (Bélanger \& Carter, 2012)

\section{Performance Measurement}

Assessing the development and performance of e-Government means determining a quantity, one of which can be given through the Maturity Level assessment by referring to the COBIT Framework.

By implementing an online system, many benefits can be learned. With this online system, you can save costs because the process of sending data is done online. This system can also be used to access the internet with faster file download/upload access.

Seeing the condition of the infrastructure that is so adequate and running well, as well as the existence 
of e-Government that is running, it is necessary to take advantage of this facility, and it is essential to develop the existing system as optimally as possible by doing what things need to be developed through this infrastructure. Convince the author to fill this network by building an application to meet the community's needs and benefit all parties, namely applications that are administrative in nature, used to empower government and explore the potential of the village.

The author will do this research into eGovernment Information System for Government Empowerment and the potential of Web-Based Villages in the Sragen Regency Government because many things in decision making must be supported by this system, such as the importance of village apparatus management. In contrast, in developing human resources of village officials, Accurate information/data is needed from the village apparatus; there are village potentials that have not been covered in development policymaking such as tourism, culture, agriculture, plantation, industry, human resources, natural resources by various SKPDs, fast information is needed investors who will invest by looking at indicators of business opportunities in the village.

For investors, information about investment potential and the village's investment climate is needed as a consideration in making location decisions for investment. But this is not sufficient to the extent of the availability of information. Efforts are required to provide a more comprehensive picture of the investment climate in various villages to help investors decide where to invest. Therefore, to deliver intensive, efficient and effective information services in order to attract investment and promote the potential of villages in the broader scope, it is necessary to build and develop an electronic government application for the Delivery of Village Potential and Investment Opportunities in Sragen Regency so that it can help potential investors to make investment decisions.

To support this program, it is necessary to keep all elements of society, especially the Village Government, to empower the potential that exists in their respective villages, where Empowerment is part of the development paradigm that focuses attention on all the principal aspects of humans in their

environment, namely starting from the intellectual aspect. Human material and physical aspects, to managerial elements. The village government, as the spearhead of development, needs serious attention. It requires hard work from all parties. All aspects of society are expected to provide accurate information about the village government and its potential to be included in the application to be built. This research focuses on developing applications that can present village government data and explore village potentials in more detail in the Sragen Regency Government. Researchers in collecting data through observation, interview methods and documentation methods. The system that the author will build is web-based, where applications and databases are centralized on the server, and applications can be accessed directly from each village with the available username and password. Finally, all data will be integrated both at the subdistrict and district levels. The research, which takes the theme: "E-Government Information System for Government Empowerment and Web-based Village Potential in the Sragen Regency Government", is expected to be able to meet the everyday information needs regarding village governance and its potential, which will be used as a basis for making development policies so that more directed and right on target, and able to bring in investors to invest which in turn can improve the welfare of the village community.

\section{CONCLUSION}

Many local governments have initiated egovernment innovation in recent years. Indeed, various efforts must be made to be able to improve the quality of e-government implementation further. The achievement of e-government will also be one of the manifestations of intelligent government, in

which a competent government is an essential component that will support the achievement of a smart city in a more comprehensive manner. In this research, several best practice controls for a system's life cycle process have been elaborated. From the study conducted, it can be seen that there is a need for an implementation stage and a control process in the eGovernment lifecycle. 


\section{REFERENCES}

[1] Al-Sobhi, F., Weerakkody, V., \& Kamal, M. M. (2010). An exploratory study on intermediaries' role in delivering public services in Madinah City: Case of Saudi Arabia and transforming Government: People, Process and Policy.

[2] Apostolou, D., Mentzas, G., Stojanovic, L., Thoenssen, B., \& Lobo, T. P. (2011). A collaborative decision framework for managing changes in e-Government services. Government Information Quarterly, 28(1), 101-116.

[3] Aprianty, D. R. (2016). Implementation of egovernment policies in improving the quality of public services at the Sambutan District office. Samarinda City, 4(4): 1589-1602.

[4] Arduini, D., Belotti, F., Denni, M., Giungato, G., \& Zanfei, A. (2010). Technology adoption and innovation in public services the case of egovernment in Italy. Information economics and policy, 22(3), 257-275.

[5] Bélanger, F., \& Carter, L. (2012). Digitizing government interactions with constituents: a historical review of e-government research in information systems. Journal of the Association for Information Systems, 13(5), 1.

[6] Coursey, D., \& Norris, D. F. (2008). Models of egovernment: Are they correct? An empirical assessment. Public administration review, 68(3), 523-536.

[7] Gajendra, S., Xi, B., \& Wang, Q. (2012). Egovernment: Public participation and ethical issues. Journal of e-Governance, 35(4), 195-204.

[8] Hiller, J. S., \& Bélanger, F. (2001). Privacy strategies for electronic government. $E$ government, 200(2001), 162-198.

[9] Irani, Z., Love, P. E., Elliman, T., Jones, S., \& Themistocleous, M. (2005). Evaluating egovernment: learning from the experiences of two UK local authorities. Information Systems Journal, 15(1), 61-82.

[10] Layne, K., \& Lee, J. (2001). Developing Fully Functional E-Government: A Four-Stage Model. Government Information Quarterly, 18 (2), 122-136.

[11] Mohamed, Y. A. (2020). ICT adoption framework for improved hospitality and tourism industry's improved operational performance: a case study of Zanzibar island hotels (Doctoral dissertation, The University of Dodoma).

[12] Moon, M. J., \& Norris, D. F. (2005). Does managerial orientation matter? The adoption of reinventing government and e-government at the municipal level. Information systems journal, 15(1), 43-60.
[13] Osei, K. A. (2017). E-government and public service quality in Ghana. Journal of Public Affairs, 17(3), 1620-1642.

[14] Rahman, Y., Riyani, I., Darmawan, D., Khairani, I. F. S. R., \& Rohmana, J. A. (Eds.). (2018). ICONQUHAS 2018: Proceedings of the 2nd International Conference on Quran and Hadith Studies Information Technology and Media in Conjunction with the 1st International Conference on Islam, Science and Technology, ICONQUHAS \& ICONIST, Bandung, October 24, 2018, Indonesia. European Alliance for Innovation.

[15] Rose, J., Persson, J. S., Heeager, L. T., \& Irani, Z. (2015). Managing e-Government: value positions and relationships. Information Systems Journal, 25(5), 531-571.

[16] Schelin, S. H. (2007). E-government: an overview. Modern public information technology systems: Issues and challenges, 110-126.

[17] Zouridis, S., \& Thaens, M. (2003). E-government: towards a public administration approach. Asian journal of public administration, 25(2), 159-183. 